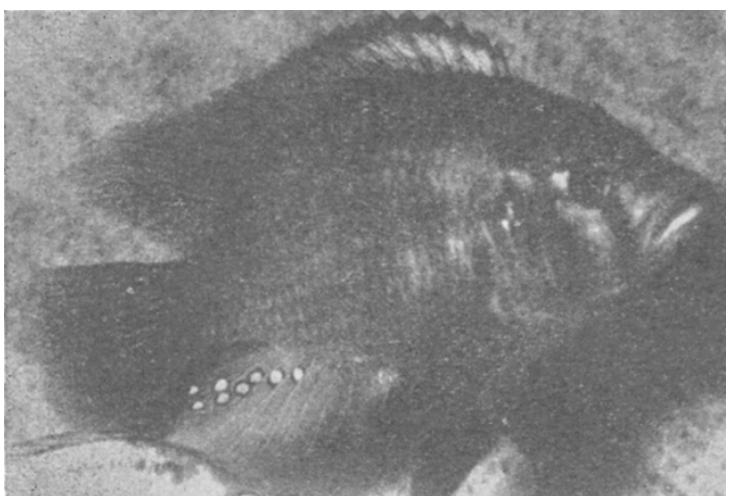

Fig. 1. Male fish of Haplochromis wingatii, showing eight annular spots on his anal fin

A second large group of mouth-breeding cichlids in Africa is formed by the genus Tilapia. Here, too, this specialization gives the same result: the female takes the eggs into the mouth as soon as they are laid. So these animals have to overcome the same difficulty of getting their eggs fertilized. Here, the females are often seen to nibble at the male's genital papilla, which is bright white or yellow, contrasting well with the dark ventral surface of the male fish. In some species of Tilapia the males bear 'genital tassels', long appendages of their genital papillæ, consisting of bifid semi-transparent filaments, festooned with bright orange blobs of tissue. Since in colour and form they resemble the eggs of the respective species, I believe that they function as 'egg-dummies'.

Both types of egg-models are attributes of the nuptual coloration of the male. They seem to be important taxonomic characters, distinguishing the Haplochromis group and the Tilapia group. Due to their releasing function, the reaction of the female in snapping up eggs is functionally changed into snapping up the (invisible) sperm. Most of the eggs of these species are thus fertilized when in the mouth of the female.

Max-Planck-Institut für

WOLFGANG WICKLER

Verhaltensphysiologie,

Seewiesen b. Starnberg, Germany.

\section{Weight and Length in the River Lamprey}

Normally the length of vertebrates (including fish $^{1,2}$ ) does not become reduced even during prolonged fasting. This rule does not apply to the cyclostomes. The river lamprey, Lampetra fluviatilis (L.) Gray, is known to undergo a considerable shortening (up to 27 per cent ${ }^{3,4}$ ) during the months between its migration from the sea to the rivers in autumn and the spawning and ensuing death in spring. In this period the animals do not eat, and their gut is reduced.

The reduction in length during fasting of course tends to keep the proportion between weight and length of the animals constant, so it would be interesting to examine to what degree this is accomplished. Therefore the weight and length of single river lampreys were followed in this laboratory from October until spawning. One batch of animals came trom Sweden and the other from Denmark. These results were combined with those of Lanzing ${ }^{5}$, who measured batches of river lampreys in the Netherlands caught during August-March.

Fig. 1 shows that the data representing the result of fasting fall around a straight line, if plotted on double logarithmic paper. The starved animals do not differ much from the well-nourished ones just coming from the sea, so instead of becoming extremely lean like other severely fasting vertebrates, the river lampreys maintain rather normal proportions (until spawning). The straight line signifies that the reduction in weight and length is allometric (weight $=a \times$ length $^{n}$ ); the line is likely to be identical with the growth-curve of these animals. Zanandrea ${ }^{6}$ measured batches of river lampreys caught in sea water while still feeding; their growth is allometric, the growth-curve running parallel to the straight line in Fig. 1. It would be interesting to see how these growing animals become reduced in weight and length if they were submitted to fasting. Presumably they would follow the same curve 'backwards'.

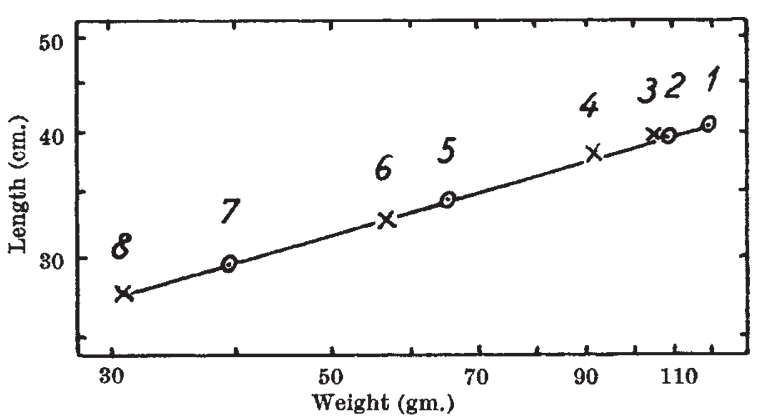

Fig. 1. Relationship between weight and length in Lampetra fluviatilis. $\odot$, Recently caught, non-fasting animals; freshwater; $x$, fasting for a long time. Place and time of capture and number of animals: (1) Meuse, Netherlands, October, 70 (ref. 5); (2) Meuse, 70 (ref. 5); (4) Meuse, Netherlands, March, 70 (ref. 5); (5) Varde aa, Denmark, October, 10, measured 1 month after arrival; (6) Varde aa, Denmark, October, 10, measured in February; (7) Dalallv, sweden, October, 11 , measured 1 month after arrival; (8) Dalälv, Sweden, October, 11, measured in February

Under certain conditions the body proportions are altered. Some time before spawning, presumably at the time of ovulation, the females gain in weight and become swollen; but their length is still decreasing, sometimes even faster than before. Moreover, animals disturbed by transport seem to gain in weight by uptake of water (increased permeability of the skin $^{2}$ ); this is followed by a large decrease in bodyweight observed after 2 weeks in the laboratory; these fluctuations in body-weight are accompanied by the usual slow shortening.

The relation between weight and length during the life-time of the river lampreys is thus quite different from that found in other vertebrates. The lack of a skeleton and the nature of the chorda may make the shortening possible. Shortening during fasting was observed in planarians ${ }^{7}$ and is probably not uncommon in other animals which do not possess a stiff exo- or endo-skeleton.

Zoophysiological Laboratory $A$,

University of Copenhagen.

${ }^{1}$ Brown, M. E., in The Physiology of Fishes, edit. by Brown, M. E. 1, Chap. 9 (Academic Press, 1957)

${ }^{2}$ Ciaccio, G., Atti Ist. Veneto Sci. Lett. Arti, 103, 133 (1943-44).

${ }^{3}$ Cotronei, G., Pubbl. Staz. Zool. Napoli, 8, 371 (1927).

${ }^{4}$ Ivanova-Berg, M. M., Arch. Hydrobiol., 25, 22 (1933).

- Lanzing, W. J. R., Studies on the River Lamprey, Lampetra fuviatilis, nzing, W. J. R., Studies on the River Lamprey, Lampetra fuviatilis,
during its Anadromous Migration (Uitgeversmatschappii

- Zanandrea, G., Pubb. Staz. Zool. Napoli, 31, 265 (1959).

7 Hyman, L. H., Amer. J. Physiol., 53, 399 (1920). 